\title{
VARIASI KOMPOSISI GRADASI BATUAN TERHADAP KARAKTERISTIK BETON ASPAL DENGAN UJI MARSHALL
}

\author{
Ramlan $^{1}$ \\ ${ }^{1}$ Pegawai Dinas PU Luwu Utara \\ ramlan.pu16@gmail.com
}

\begin{abstract}
Abstrak
Hasil penelitian menunjukkan bahwa Menurunnya nilai stabilitas, disebabkan dengan semakin bertambahnya jumlah mastik dan turunnya nilai viskositas akibat bertambahnya ukuran butiran agregat kasar, yang pada awalnya turut membantu menaikkan stabilitas, tetapi karena mastiknya terus bertambah dan mulai berlebih, hal ini akan mengakibatkan ikatan antar butiran menjadi lemah, akhirnya menurunkan nilai stabilitas. Sehingga kemampuan agregat untuk menahan beban deformasi yang diberikan berkurang Nilai stabilitas tertinggi pada komposisi V dengan nilai 1764,548 Kg dan batas spesifikasi untuk beton aspal sebesar minimal $800 \mathrm{~kg}$. Marshal Quintent terhadap variasi komposisi agregat kasar nilai Marshall Quotient bertambah akibat adanya penambahan jumlah agregat kasar yaitu pada komposisi I, II, III dan V hal ini mengindikasikan aspal yang melekat dan terabsorsi kedalam agregat mampu memperkuat campuran sehingga tahan terhadap beban deformasi. Pada komposisi agregat kasar IV dan VI nilai Marshall Quotient turun ini disebabkan oleh aspal tidak dapat lagi melekat dipermukaan agregat secara maksimal sehingga kemampuan untuk melawan beban deformasi semakin berkurang. Spesifikasi Density untuk aspal beton $1.8-5 \mathrm{Kg} / \mathrm{mm}$.
\end{abstract}

Kata kunci : Gradasi, Beton Aspal, Uji Marshall

\section{PENDAHULUAN}

Beton Aspal yang biasa disebut dengan Laston digunakan pada jalan dengan beban lalu lintas yang tinggi, kemiringan yang curam, persimpangan dan daerah yang dilalui oleh beban roda kendaraan berat. Perkerasan aspal beton terdiri dari dua bahan utama, yaitu agregat dan aspal. Bahan-bahan campuran aspal beton yang terdiri dari agregat kasar, agregat halus, bahan pengisi dan bahan pengikat, dipanaskan dan dicampur bersama dengan perbandingan tertentu disebuah pabrik pencampuran aspal. Setelah semua partikel agregat dilapisi aspal dengan merata, campuran yang masih panas ini dihamparkan dengan mesin penghampar di lokasi pembangunan konstruksi jalan yang telah dipersiapkan sebelumnya. Kemudian campuran tersebut langsung dipadatkan dalam keadaan panas dengan menggunakan mesin pemadat atau penggilas sehingga mencapai suatu kepadatan tertentu.

Kerusakan dini pada perkerasan sering terlihat dalam bentuk retak (cracking), kelelehan (bleeding) dan alur (rutting). Laston dapat mengurangi keretakan karena daya tahan dan kelenturan yang tinggi, tetapi mempunyai kelemahan lainnya, seperti kelelehan dan alur. Daya tahan (durabilitas) campuran aspal dapat ditingkatkan dengan menaikkan kadar bahan pengikat. Persyaratan ini bertentangan dengan stabilitas tinggi yang didapat pada kadar bahan pengikat rendah. Kadar pengikat yang digunakan sebaiknya dapat memenuhi persyaratan durabilitas dan stabilitas.

Untuk beton, aspal agregat kasar memiliki peranan utama dalam kinerja campuran sebab stabilitas aspal beton tergantung kepada ikatan dan susunan dari agregat. Agregat kasar harus memiliki ketahan terhadap keausan, terutama apabila digunakan pada campuran untuk lapis permukaan. Agregat merupakan komponen yang dominan dalam struktur perkerasan jalan. Banyak agregat yang dibutuhkan dalam pencampuran perkerasan pada umumnya berkisar antara 90\%-95\% dari berat total campuran atau $75 \%-85 \%$ dari volume campuran. Dengan perbandingan komposisi-komposisi tertentu, Persyaratan yang lebih ketat umumnya diterapkan 
pada material sebagai aggregat kasar, hal ini diperlukan karena agregat kasar memiliki peran yang besar dalam membangun struktur yang kuat dan stabil.

Berdasarkan salah satu dari sifat - sifat yang diinginkan dalam campuran aspal beton yaitu stabilitasnya, penulis mancoba meneliti campuran perkerasan aspal beton jenis AC-WC (Asphalt Conrete-Wearing Course) yang mana gradasi kasarnya utuh (saringan $3 / 4,1 / 2,3 / 8$, No.4, No.8) kemudian dari gradasi tersebut divariasikan, sehingga diperoleh beberapa komposisi gradasi dengan maksud mengetahui sejauh mana pengaruh variasi komposisi tersebut terhadap nilai stabilitas yang dihasilkan.

Agregat kasar adalah agregat yang lolos pada saringan 3/4 $(19,1 \mathrm{~mm})$ dan tertahan pada saringan No. $4(4,75 \mathrm{~mm})$ terdiri dari batu pecah atau koral (kerikil pecah) berasal dari alam yang merupakan batu endapan. Permukaan agregat kasar mempunyai gaya gesek yang baik, ikatan antar butir agregat kuat, sehingga lebih mampu menahan deformasi akibat beban lalu-lintas. Partikel agregat kasar dapat berbentuk :

a) Bulat. Agregat yang dijumpai di sungai pada umumnya telah mengalami pengikisan oleh air sehingga umumnya berbentuk bulat. Partikel agregat bulat saling bersentuhan dengan luas bidang kontak kecil sehingga menghasilkan daya yang lebih kecil dan mudah tergelincir.

b) Kubus. Partikel berbentuk kubus merupakan bentuk agregat dari hasil mesin pemecah batu yang mempunyai bidang kontak yang lebih luas, (berbentuk bidang rata) sehingga memberikan saling mengunci yang lebih besar. Agregat bentuk kubus ini paling baik digunakan sebagai bahan perkerasan jalan.

c) Pipih. Partikel agregat berbentuk pipih dapat merupakan hasil dari pemecah batu ataupun memang merupakan sifat dari agregat tersebut jika dipecahkan cenderung berbentuk agregat pipih.

Aspal didefinisikan sebagai bahan alam dengan komponen kimia utama hidrokarbon, hasil expolarasi dengan warna hitam bersifat plastis hingga cair, tidak larut dalam larutan asam encer dan alkali atau air, tapi larut sebagian besar dalam aether, CS2 bensol, Dan choloroform. Aspal cair adalah aspal keras yang di encerkan dengan 10 sampai $20 \%$ kerosin, white spirit, atau gas oil untuk mencapai viscositas tertentu dan memenuhi fraksibdestilasi tertentu. Viscositas ini dibutuhkan agar aspal tersebut dapat menutupi agregat dalam waktu yang singkat dan akan meningkat terus sampai pekerjaan pemadatan dapat dilaksanakan.

Aspal cair yaitu aspal yang berbentuk cair pada suhu ruang. Aspal cair merupakan semen aspal yang dicairkan dengan bahan pencair dari hasil penyulingan minyak bumi seperti minyak tanah, bensin, atau solar. Bahan pencair membedakan aspal cair menjadi: (1) rapid curing cutback asphalt (RC), yaitu aspal cair dengan menggunakan bahan pencair bensin, $\mathrm{RC}$ merupakan aspal cair yang paling cepat menguap; (2) medium curing cutback aspal (MC), yaitu aspal cair dengan bahan pencair minyak tanah (kerosene); (3) slow curing cutback asphalt (SC), yaitu aspal cair dengan bahan pencair solar. SC merupakan aspal cair yang paling lambat menguap.

Aspal yang dipergunakan pada konstruksi perkerasan berfungsi sebagai berikut: (1) bahan pengikat, memberikan ikatan yang kuat antara aspal dan agregat serta antara aspal itu sendiri; (2) bahan pengisi, mengisi rongga antara butir-butir agregat dan pori-pori yang ada dari agregat itu sendiri. Berarti aspal haruslah mempunyai daya tahan (tidak cepat rapuh) terhadap cuaca, mempunyai adhesi dan kohesi yang baik dan memberikan sifat elastis yang baik. 
a) Daya tahan (durability) adalah kemampuan aspal mempertahankan sifat asalnya akibat pengaruh cuaca selama masa pelayanan jalan.

b) Adhesi dan Kohesi. Adhesi adalah kemampuan aspal untuk mengikat agregat sehingga dihasilkan ikatan yang baik antara agregat dengan aspal. Kohesi adalah kemampuan aspal untuk mempertahankan agregat tetap di tempatnya setelah terjadi pengikatan.

c) Kepekaan terhadap temperatur. Aspal adalah material termoplastis, berarti akan menjadi keras atau lebih kental jika temperatur berkurang dan akan lunak atau lebih cair jika temperatur bertambah. Sifat ini dinamakan kepekaan terhadap perubahan temperatur.

d) Kekerasan aspal. Aspal pada proses pencampuran dipanaskan dan dicampur dengan agregat sehingga agregat dilapisi aspal atau aspal panas disiram ke permukaan agregat yang telah disiapkan pada proses peleburan. Pada waktu proses pelaksanaan, terjadi oksidasi yang menyebabkan aspal menjadi getas (viskositas bertambah tinggi).

Agregat didefinisikan secara umum sebagai formasi kulit bumi yang keras dan padat. ASTM mendefinisikan agregat sebagai suatu bahan terdiri dari material padat berupa masa berukuran besar atau fragmen-fragmen. Agregat merupakan komponen utama dari struktur perkerasan jalan, yang mengandung 90-95\% agregat berdasarkan persentase berat atau $75-85 \%$ agregat berdasarkan persentase volume. Dengan demikian daya dukung, keawetan dan mutu perkerasan jalan ditentukan dari sifat agregat dan hasil campuran agregat dengan material lain. Agregat halus terdiri dari bahan-bahan yang berbidang kasar, bersudut tajam dan bersih dari kotorankotoran atau bahan-bahan lain yang tidak di kehendaki.

Agregat halus bisa terdiri dari pasir bersih, bahan-bahan halus hasil pemecahan batu atau kombinasi dari bahan-bahan tersebut dan dalam keadaan kering. Agregat halus memenuhi persyaratan sebagai berikut: (1) nilai Sand Equipalent (AASHTO T-176) dari agregat min $50 \%$; (2) berat jenis semu (Apparent) (PB.0203-76) minimum 2.50 \%; (3) dari pemeriksaan Atterberg (PB.0109-76) agregat harus non plastis; (4) peresapan agregat terhadap air (PB.020276) maksimum $3 \%$.

Tabel 1. Gradasi agregat halus

\begin{tabular}{|c|c|}
\hline Ukuran saringan & Persentase lolos atau berat (\%) \\
\hline $3 / 8$ & 100 \\
\hline No. 4 & $90-100$ \\
\hline No. 8 & $80-100$ \\
\hline No. 30 & $24-100$ \\
\hline No. 200 & $3-11$ \\
\hline
\end{tabular}

Material filler dalam campuran aspal beton berperan sebagai: (1) memodifikasi gradasi agregat halus sehingga campuran lebih rapat; (2) penambahan filler akan mengurangi tingkat kehalusan aspal; (3) membentuk bahan pengikat bersama-sama dengan aspal. Sebagai filler dapat dipergunakan debu, batu kapur, debu dolomite atau semen Portland. Perlu diperhatikan agar bahan tersebut tidak tercampur dengan kotoran atau bahan lain yang tidak dikehendaki. Adapun penulis menggunakan Abu ampas tebu sebagai bahan filler. Filler harus memenuhi persyaratan sebagai berikut : 
Tabel 2. Gradasi filler

\begin{tabular}{|c|c|}
\hline Ukuran saringan & Persentase lolos atau berat (\%) \\
\hline No. 30 & 100 \\
\hline No. 50 & $95-100$ \\
\hline Ukuran saringan & Persentase lolos atau berat (\%) \\
\hline No. 100 & $70-100$ \\
\hline No. 200 & 700 \\
\hline
\end{tabular}

Gradasi adalah susunan butir agregat sesuai ukurannya. Ukuran butir agergat dapat diperoleh melalui pemeriksaan analisis saringan. Satu set saringan umumnya terdiri dari saringan berukuran 4 inci, $3^{1 / 2}$ inci, 3 inci, $2^{1 / 2}$ inci, 2 inci, $1^{1 / 2}$ inci, 1 inci, 3/4 inci, 1/2 inci, 3/8 inci, No.4, No.8, No.16, No.30, No.50, No.100, No.200. Gradasi agregat diperoleh dari hasil analisis pemeriksaan dengan mempergunakan 1 set saringan. Gradasi agregat mempengaruhi besarnya rongga atau pori antar butir yang akan menentukan stabilitas dan kemudahan dalam proses pelaksanaan. Gradasi agregat dinyatakan dalam persentase lolos, atau persentase tertahan, yang dihitung berdasarkan berat agregat. Agregat campuran yang terdiri dari agregat berukuran sama akan berongga atau berpori banyak,karena tak terdapat agregat berukuran kecil yang dapat rongga yang terjadi. Sebaliknya, jika campuran agregat terdistibusi dari agregat berukuran besar sampai kecil merata, maka rongga atau pori yang terjadi sedikit. Hal ini terbentuk oleh susunan agregat berukuran besar, akan diisi oleh agregat berukuran lebih kecil.

Distribusi butir-butir agregat dengan ukuran tertentu yang dimiliki oleh suatu campuran menentukan jenis gradasi agregat. Gradasi agregat dapat dikelompokkan kedalam agregat bergradasi baik dan buruk. Agregat bergradasi baik adalah agregat yang ukuran butirnya terdistribusi merata dalam satu rentang ukuran butir. Agregat bergradasi baik disebut pula agregat bergradasi rapat. Campuran agregat bergradasi baik mempunyai pori sedikit, mudah dipadatkan, dan mempunyai stabilitas tinggi. Tingkat stabilitas ditentukan dari ukuran butir agregat terbesar yang ada. Berdasarkan ukuran butir agregat yang dominan menyusun campuran agregat, maka agregat bergradasi baik dapat dibedakan atas: (1) agregat bergradasi kasar adalah agregat bergradasi baik yang mempunyai susunan ukuran menerus dari kasar sampai dengan halus, tetapi dominan berukuran agrgat kasar; (2) agregat bergradasi halus adalah agregat bergradasi baik yang mempunyai susunan ukuran menerus dari kasar sampai dengan halus, tetapi dominan berukuran agrgat halus.

Stabilitas adalah kemampuan perkerasan jalan menerima beban lalu lintas tanpa terjadi perubahan bentuk tetap seperti gelombang, alur, dan bleeding. Kebutuhan akan stabilitas sebanding dengan fungsi jalan, dan beban lalu lintas yang akan dilayani. Jalan yang melayani volume lalu lintas tinggi dan dominan terdiri dari kendaraan berat, membutuhkan perkerasan jalan dengan stabilitas tinggi. Sebaliknya perkerasan jalan yang diperuntukkan untuk melayani lalu lintas kendaraan ringan tentu tidak perlu mempunyai nilai stabilitas yang tinggi.

Keawetan atau durabilitas adalah kemampuan beton aspal menerima repetisi beban laluy lintas seperti berat kendaraan dan gesekan antara roda kendaraaan dan permukaan jalan, serta menahan keausan akibat pengaruh cuaca dan iklim, seperti udara, air, atau perubahan temperatur. Durabilitas beton aspal dipengaruhi oleh tebalnya film atau selimut aspal. Selimut aspal yang tebal akan membungkus agregat secara baik, beton aspal akan lebih kedap air, sehingga kemampuannya menahan keausan semakin baik. Tetapi semakin tebal selimut aspal, maka semakin mudah 
terjadi bleeding yang mengakibatkan jalan semakin licin. Besarnya pori yang tersisa dalam campuran setelah pemadatan, mengakibatkan durabilitasi beton aspal menurun. Semakin besar pori yang tersisa semakin tidak kedap air dan semakin banyak udara di dalam beton aspal,yang menyebabkan semakin mudahnya selimut aspal beroksidasi dengan udara dan menjadi getas, dan durabilitasinya menurun.

Kelenturan atau fleksibilitas adalah kemampuan beton aspal untuk menyesuaikan diri akibat penurunan (konsolidasi/settlement) dan pergerakan dari pondasi atau tanah dasar, tanpa terjadi retak. Penurunan terjadi akibat dari repetisi beban lalu lintas, ataupun penurunan akibat berat sendiri tanah timbunan yang dibuat di atas tanah asli.

Kekesatan/tahanan geser adalah kemampuan permukaan beton aspal terutama pada kondisi basah, memberikan gaya gesek pada roda kendaraan sehingga kendaraan tidak tergelincir, ataupun slip. Faktor-faktor untuk mendapatkan kekesatan jalan sama dengan untuk mendapatkan stabilitas yang tinggi, yaitu kekasaran permukaan dari butir - butir agregat, luas bidang kontak antar butir atau bentuk butir, gradasi agregat, kepadatan campuran, dan tebal film aspal. Ukuran maksimum butir agregat ikut menentukan kekesatan permukaan.

Kedap air (impermeabilitas) adalah kemampuan beton aspal untuk tidak dapat dimasuki air ataupun udara ke dalam lapisan beton aspal. Air dan udara dapat mengakibatkan percepatan proses penuaan aspal, dan pengelupasan film/selimut aspal dari permukaan agregat. Jumlah pori yang tersisa setelah beton aspal dipadatkan dapat menjadi indikator kekedapan air campuran. Tingkat impermeabilitas beton aspal berbanding terbalik dengan tingkat durabilitasnya.

Aspal beton banyak digunakan untuk jalan dengan beban lalulintas yang tinggi dan berat, persimpangan, kondisi di mana lapis permukaan akan mengalami tekanan roda kendaraan secara berlebihan, kondisi geometric dengan keadaan yang berjenjang (tikungan tajam, tanjakan, turun). Aspal beton dikategorikan menjadi 11 (sebelas) batas - batas gradasi menerus agregat campuran yaitu AC I, AC II, AC III, AC IV, AC V, AC VI, AC VII, AC VIII, AC IX, AC X, AC XI.

Aspal yang digunakan untuk lapis aspal beton harus terdiri dari aspal keras penetrasi 60/70. Pemelihan pemakaian jenis aspal didasarkan pada kondisi cuaca setempat dan volume lalu-lintas yang akan melaluinya. Pada daerah panas dengan volume lalu-lintas yang tinggi biasanya menggunakan aspal dengan penetrasi yang rendah. Demikian juga sebaliknya pada daerah yang dingin dengan volume lalu lintas yang rendah menggunakan aspal dengan penetrasi yang tinggi.

\section{HASIL DAN PEMBAHASAN}

Stabilitas adalah kemampuan perkerasan jalan menerima beban lalulintas tanpa terjadi perubahan bentuk tetap seperti gelombang, alur dan bleeding. Pada penelitian mengenai variasi komposisi agregat kasar dan pengaruhnya terhadap stabilitas dalam campuran aspal beton dapat dilihat pada grafik dibawah ini. 


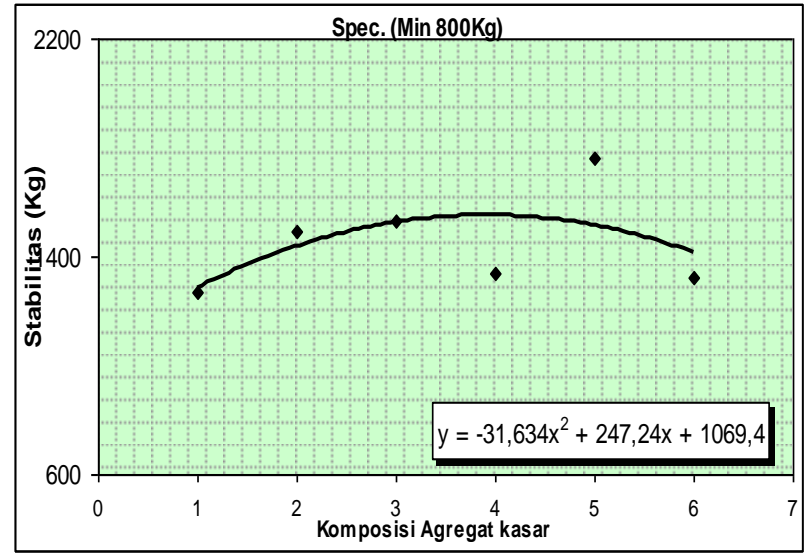

Gambar 1. Variasi komposisi agregat

Peningkatan nilai stabilitas ini disebabkan oleh pemilihan agregat bergradasi baik atau rapat yang mana akan memperkecil antar rongga antara agregat, pengaruh dari gesekan internal, yang dapat berasal dari kekasaran permukaan dari butir-butir agregat, luas bidang kontak antar butir atau bentuk butir, gradasi agregat, kepadatan campuran, dan tebal film aspal. Stabilitas terbentuk dari kondisi gesekan internal yang terjadi di antara butir-butir agregat, saling mengunci dan mengisinya butir-butir agregat, dan masing-masing butir saling terikat, akibat gesekan antar butir dan adanya aspal. Daya absorbsi akan menyebabkan kohesi campuran bertambah, kerapatan campuran meningkat sehingga akan meningkatkan bidang kontak antar agregat dan meningkatkan interlocking antar agregat yang pada akhirnya meningkatkan nilai stabilitas.

Sedangkan penurunan nilai stabilitas lebih disebabkan mempunyai butiran lebih halus yang mengakibatkan lebih mudah bercampur dengan aspal membentuk mastik yang memiliki viskositas lebih rendah. Dengan semakin bertambahnya jumlah mastik dan turunnya nilai viskositas akibat bertambahnya ukuran butiran agregat kasar, yang pada awalnya turut membantu menaikkan stabilitas, tetapi karena mastiknya terus bertambah dan mulai berlebih, hal ini akan mengakibatkan ikatan antar butiran menjadi lemah, akhirnya menurunkan nilai stabilitas.

Flow (kelelahan) adalah deformasi vertikal yang terjadi mulai awal pembebanan sampai kondisi stabilitas menurun, yang menunjukkan besarnya deformasi yang terjadi pada lapis perkerasan akibat menahan beban yang diterimanya.

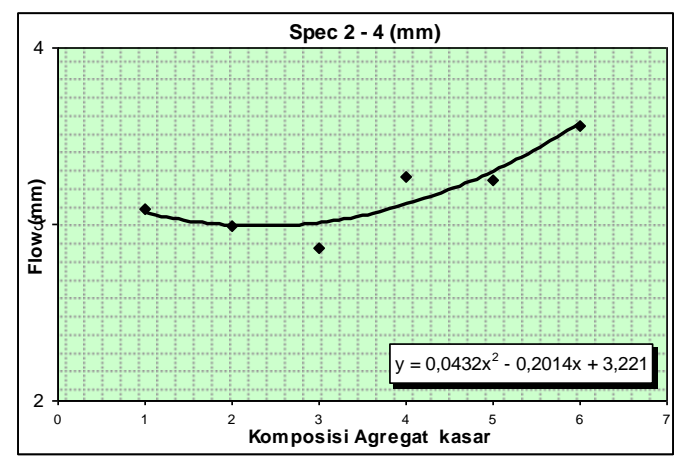

Gambar 2. Hubungan variasi komposisi agregat kasar terhadap nilai flow pada campuran beton aspal 
Nilai flow dipengaruhi oleh kadar aspal, viscositas aspal, gradasi agregat, jumlah dan temperatur pemadatan. Grafik diatas menunjukkan dengan berkurangnya prosentase agregat kasar, nilai flow menunjukkan kecendrungan membesar. Peningkatan nilai flow ini disebabkan prosentase agregat kasar yang digunakan dimana semakin sedikit prosentase agregat kasar yang digunakan akan memperkecil antar rongga agregat dalam campuran menyebabkan campuran menjadi lebih plastis dan jika menerima beban mengalami depormasi plastis yang lebih besar.

Rongga udara (VIM) menunjukkan prosentase rongga dalam campuran. Dengan kata lain VIM (Rongga di dalam Campuran) adalah parameter yang menunjukkan volume rongga yang berisi udara didalam campuran beraspal, dinyatakan dalam \% volume. Nilai VIM berpengaruh terhadap keawetan dari campuran aspal agregat, semakin tinggi nilai VIM menunjukkan semakin besar rongga dalam campuran sehingga campuran bersifat porus, semakin tinggi nilai VIM kondisi campuran aspal semakin rapuh. Untuk campuran aspal beton nilai VIM dibatasi dalam spesifikasi $1.8-5 \%$

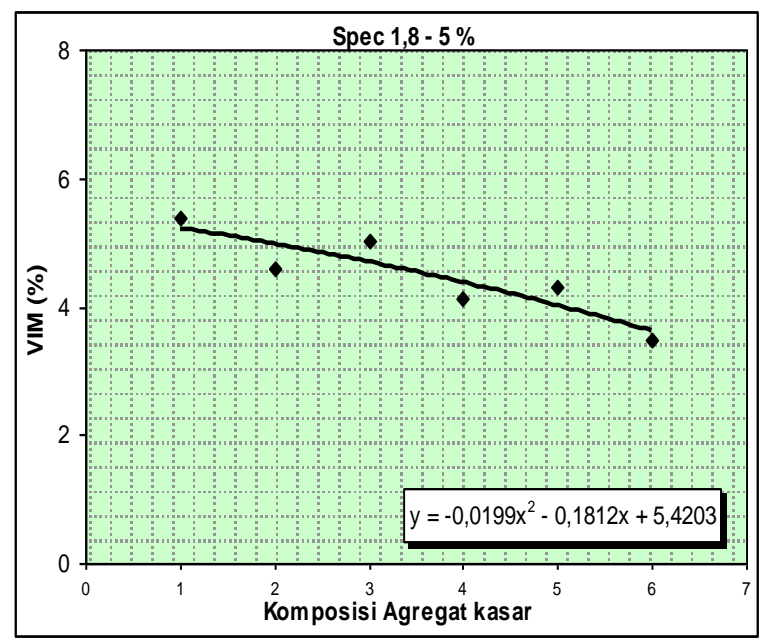

Gambar 3. Hubungan variasi komposisi agregat terhadap VIM pada campuran beton aspal

Grafik diatas menunjukkan bahwa semakin besar prosentase agregat kasar, nilai VIM semakin kecil. Hal ini disebabkan karena adanya kemampuan dari agregat kasar untuk mengambil air yang ada pada agregat, sehingga meningkatkan adesi antara agregat dengan aspal mengakibatkan ikatan antar agregat semakin kuat, dengan adanya energi pemadat campuran menjadi semakin rapat maka ruang yang tersisa semakin kecil.

VMA adalah rongga antar butiran agregat yaitu rongga udara yang ada diantara partikel campuran agregat aspal yang sudah dipadatkan termasuk ruang yang terisi aspal yang dinyatakan dalam persen terhadap total volume campuran agregat aspal. Faktor yang mempengaruhi VMA antara lain adalah gradasi agregat (komposisi campuran agregat dan ukuran diameter butir terbesar), energi pemadat, kadar aspal dan bentuk butiran 


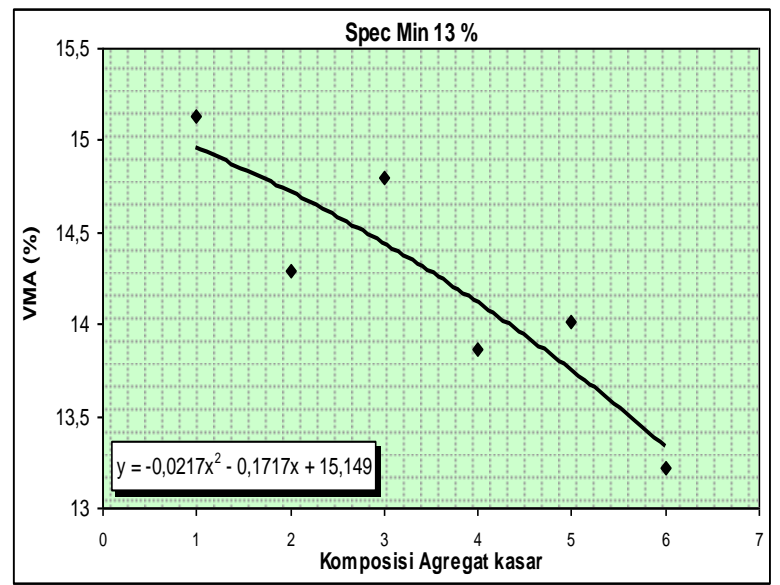

Gambar 4. Hubungan variasi komposisi agregat kasar terhadap VMA pada campuran beton aspal

Dari grafik diatas menunjukkan semakin besar komposisi agregat kasar, nilai VMA semakin mengecil. Hal ini disebabkan karena agregat kasar yang bertindak sebagai agregat pokok dengan mengambil air yang masih tersisa pada agregat lain, dengan demikian akan meningkatkan adhesi antara agregat dengan aspal, ditambah dengan adanya energi pemadat maka campuran akan semakin padat, memperkecil ruang antar butiran agregat. Untuk campuran aspal beton nilai VIM dibatasi dalam spesifikasi Min $13 \%$.

VFA adalah rongga terisi aspal pada campuran setelah mengalami proses pemadatan yang dinyatakan dalam persen terhadap rongga antar butiran agregat (VMA), sehingga antara nilai VFA dengan VMA mempunyai kaitan yang sangat erat dengan kata lain VFA adalah bagian dari VMA yang terisi oleh aspal yang terabsorsi oleh masing-masing agregat. Dengan demikian, aspal yang mengisi VFA adalah aspal yang berfungsi untuk menyelimuti butir-butir agregat dalam beton aspal padat, atau volume beton aspal padat yang menjadi film atau selimut aspal. Faktor-faktor yang mempengaruhi VFA antara lain kadar aspal, gradasi agregat, energi pemadat (jumlah dan temperatur pemadatan) dan absorbsi agregat.

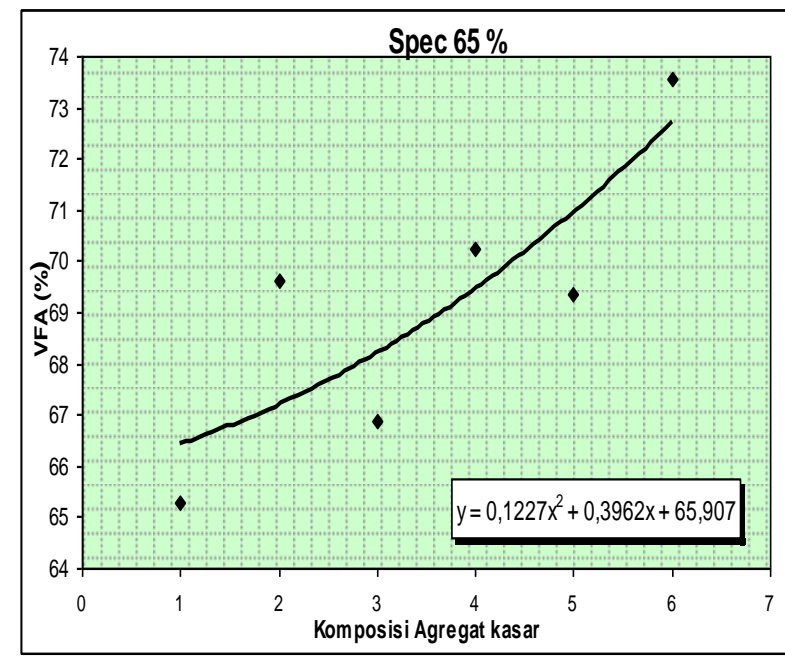

Gambar 5. Hubungan variasi komposisi agregat kasar terhadap VFA pada campuran beton aspal. 
Pada grafik diatas memperlihatkan semakin besar variasi komposisi agregat kasar, nilai VFA menunjukkan kecendrungan semakin membesar. Hal ini disebabkan agregat kasar memiliki butiran lebih besar sehingga lebih mudah terselimuti dengan aspal membentuk mastik yang memiliki viscositas lebih rendah. Dengan bertambahnya agregat kasar dalam campuran, jumlah mastik juga akan meningkat sehingga campuran lebih mudah dipadatkan menyebabkan nilai VMA mengecil. Mengecilnya nilai VMA pada kadar aspal yang tetap, berakibat memperbesar prosentase rongga terisi aspal (VFA).

Nilai density adalah nilai berat volume untuk menunjukkan kepadatan dari campuran beton aspal. Faktor-faktor yang mempengaruhi density adalah temperatur pemadatan, komposisi bahan penyusun, kadar filler, energi pemadat dan kadar aspal. Semakin tinggi nilai stabilitasnya, maka nilai densitynya (kepadatannya) juga naik sampai dengan density maksimumnya, karena pada kondisi tersebut campuran sudah dalam keadaan padat. Pemadatan adalah suatu proses pekerjaan yang pada umumnya didapatkan dengan dengan alat-alat mekanis, untuk mengurangi rongga-rongga campuran yang terlalu besar, sehingga butiran bahan tersebut tersusun rapat satu sama lain dan saling mengikat dengan aspal.

Pada penelitian mengenai variasi komposisi agregat kasar dan pengaruhnya terhadap density dalam campuran aspal beton dapat dilihat pada grafik dibawah ini.

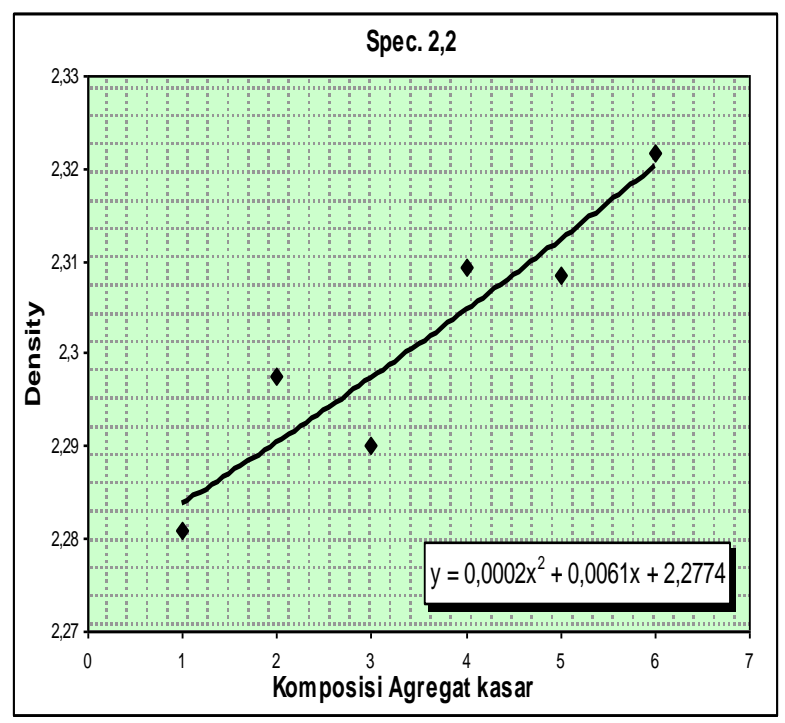

Gambar 6. Hubungan variasi komposisi agregat kasar terhadap density pada campuran beton aspal

Pada grafik diatas menunjukkan semakin besar variasi komposisi agregat kasar dapat menaikkan nilai density. Hal ini disebabkan karena agregat kasar mempunyai butiran lebih besar yang mengakibatkan lebih mudah bercampur dengan aspal membentuk mastik yang memiliki viskositas lebih rendah. Akibat bertambahnya jumlah agregat pokok dalam campuran, jumlah mastik dalam campuran semakin bertambah dengan viskositas semakin rendah, sehingga mastik akan mudah masuk kedalam rongga antar butiran agregat yang mengakibatkan campuran semakin mudah dipadatkan dan nilai density naik. Spesifikasi Density untuk aspal beton min 2.2.

Marshall Quotient adalah nilai pendekatan yang hampir menunjukkan nilai kekakuan suatu campuran beraspal dalam menerima beban. Nilai MQ diperoleh dari 
perbandingan antara nilai stabilitas yang telah dikoreksi terhadap nilai kelelehan (flow), dan dinyatakan dalam satuan $\mathrm{kg} / \mathrm{mm}$ atau $\mathrm{kN} / \mathrm{mm}$.

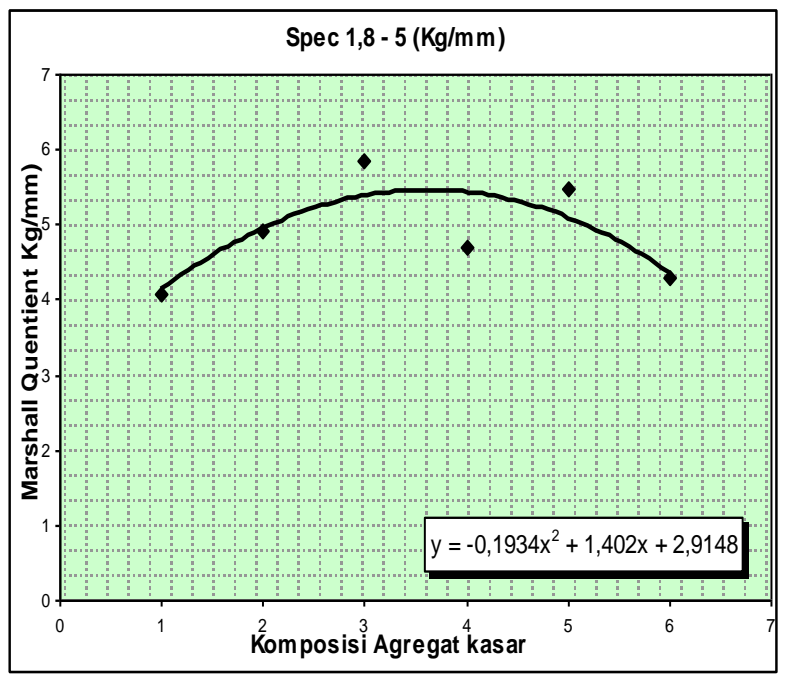

Gambar 7. Hubungan variasi komposisi agregat kasar terhadap Marshall Quotient pada campuran beton aspal

Pada grafik diatas menunjukkan nilai Marshall Quotient bertambah akibat adanya penambahan jumlah agregat kasar yaitu pada komposisi I, II, III dan V hal ini mengindikasikan aspal yang melekat dan terabsorsi kedalam agregat mampu memperkuat campuran sehingga tahan terhadap beban deformasi. Pada komposisi agregat kasar IV dan VI nilai Marshall Quotient turun ini disebabkan oleh aspal tidak dapat lagi melekat dipermukaan agregat secara maksimal sehingga kemampuan untuk melawan beban deformasi semakin berkurang. Spesifikasi Density untuk aspal beton $1.8-5 \mathrm{Kg} / \mathrm{mm}$.

\section{PENUTUP}

Menurunnya nilai stabilitas, disebabkan Dengan semakin bertambahnya jumlah mastik dan turunnya nilai viskositas akibat bertambahnya ukuran butiran agregat kasar, yang pada awalnya turut membantu menaikkan stabilitas, tetapi karena mastiknya terus bertambah dan mulai berlebih, hal ini akan mengakibatkan ikatan antar butiran menjadi lemah, akhirnya menurunkan nilai stabilitas. Sehingga kemampuan agregat untuk menahan beban deformasi yang diberikan berkurang Nilai stabilitas tertinggi pada komposisi V dengan nilai 1764,548 $\mathrm{Kg}$ dan batas spesifikasi untuk beton aspal sebesar minimal $800 \mathrm{~kg}$. Flow, terhadap variasi komposisi agregat kasar, nilai flow menunjukkan kecendrungan membesar. Peningkatan nilai flow ini disebabkan prosentase agregat kasar yang digunakan dimana semakin sedikit, nilai Flow tertinggi pada komposisi VI dengan nilai 3,56 $\mathrm{mm}$. Air Void (VIM), terhadap variasi komposisi agregat kasar, semakin tinggi nilai VIM menunjukkan semakin besar rongga dalam campuran sehingga campuran bersifat porus, nilai VIM tertinggi pada Komposisi I dengan nilai 5,381 \% Untuk campuran aspal beton nilai VIM dibatasi dalam spesifikasi 1.8-5\%.

VMA, terhadap variasi komposisi agregat kasar, semakin besar komposisi agregat kasar, nilai VMA semakin mengecil. Hal ini disebabkan karena agregat kasar yang bertindak sebagai agregat pokok. Nilai VMA tertinggi pada Komposisi I dengan nilai $15,1 \%$ untuk campuran beton aspal nilai VMA dibatasi dalam 
spesifikasi Min $13 \%$. Dengan bertambahnya agregat kasar dalam campuran, jumlah mastik juga akan meningkat sehingga campuran lebih mudah dipadatkan menyebabkan nilai VMA mengecil. Mengecilnya nilai VMA pada kadar aspal yang tetap, berakibat memperbesar prosentase rongga terisi aspal (VFA). Nilai VFA tertinggi pada Komposisi VI dengan nilai 73,56 \% Untuk campuran aspal beton nilai VFA dibatasi dalam spesifikasi Min $65 \%$. Pada komposisi agregat kasar IV dan VI nilai Marshall Quotient turun ini disebabkan oleh aspal tidak dapat lagi melekat dipermukaan agregat secara maksimal sehingga kemampuan untuk melawan beban deformasi semakin berkurang. Spesifikasi Density untuk aspal beton $1.8-5 \mathrm{Kg} / \mathrm{mm}$.

\section{DAFTAR PUSTAKA}

Saodang, Hamirhan. 2004. Konstruksi Jalan Raya, jilid 2, nova, Bandung.

Sukirman, Silvia 2003. Beton Aspal Campuran Panas, Granit, Jakarta.

Sukirman, Silvia 1995, Pekerasan Lentur Jalan Raya, nova, Bandung.

Sulaksono, Sony 2001 Rekayasa jalan SI - 374, ITB, Bandung.

Tm, Suprapto. 2004, Bahan Struktur Jalan Raya, Jilid III, Biro Penerbit, Yogyakarta. 
PENA TEKNIK: Jurnal Ilmiah Ilmu-Ilmu Teknik

Volume 1, Nomor 1, Maret 2016: 1 - 12 